УДК 305:355.11

DOI https://doi.org/10.32838/2663-5984/2021/4.29

\title{
Мараєва В.B.
}

Науково-дослідний центр гуманітарних проблем Збройних Сил України

\section{Данілевська О.В.}

Науково-дослідний центр гуманітарних проблем Збройних Сил України

\section{IНТЕГРАЦІЯ ГЕНДЕРНОЇ РІВНОСТІ ТА РІЗНОМАНІТНОСТI У ЗБРОЙНІ СИЛИ: ДОСВІД КРАЇН-ЧЛЕНІВ НАТО}

Гендерна інтеграчія є основою формування гендерної ментальності та визначається як стратегія, щьо використовується для досягнення гендерної рівності у Збройних силах через активізачію залучення як жінок, так і чоловіків до виконання завдань за призначенням на всіх рівнях. У країнах-членах НАТО для реалізації бачення сучасних, різноманітних Збройних сил, здатних залучати й утримувати талановиті кадри, визнають необхідність нових ініціатив і підвищення рівня культурної трансформації в усіх сферах. Пріоритетними напрямами визначені подолання бар'єрів для вербування, утримання та просування по службі жінок та інших груп, які традиційно недостатньо представлені у Збройних силах, протистояння гендерним домаганням, дискримінації та зловжсиванням. У НАТО твердо закріплені та постійно допрацьовуються політичні рамки та керівні вказівки щзодо заохочення гендерної рівності та різноманітності. Серед найбільш неврегульованих проблем залишаються насильство на сексуальному і гендерному трунті в умовах конфліктів, відсутність ефективних інститучійних механізмів захисту представників гендерних, расових, релігійних меншин, недостатня участь жінок у мирному процесі тощо. Ці та інші питання залитаються сьогодні вкрай актуальними.

У пропонованій статті на прикладах США та Німеччини розглядається досвід крайн-членів НАТО щуодо інтеграції гендерної рівності та різноманітності у Збройні сили. 3'ясовано, що аргументи противників гендерної рівності, які стосувалися фізичної та психологічної неспроможності жінок проходити військову службу, проблем забезпечення згуртованості, боєготовності та підтримки морального духу підрозділу, були неодноразово спростовані соиіологічними дослідженнями. Останніми роками у деяких країнах відбулися швидкі зміни у законах і політиці щодо різноманітності, включеності та рівних можливостей, зокрема щодо жінок, котрі служать за бойовими спеціальностями, та включення ЛГБТ-осіб до особового складу Збройних сил. I хоча деякі з иих змін залишаються суперечливими та мають постійні юридичні виклики, ией досвід заслуговує на увагу науковиів.

Ключові слова: гендер, гендерна рівність, НАТО, армії країн-членів НАТО, інтеграчія різноманітності у Збройні сили, дискримінація за ознакою статі.

Постановка проблеми. Гендерна рівність - це не лише одне з основних прав людини, а й необхідна основа досягнення миру, процвітання та сталого розвитку. НАТО надає незмінну підтримку боротьбі за гендерну рівність та інтеграції різноманітності до Збройних сил. Включення тематики різноманітності та гендерної рівності в усі основні принципи, процеси та практичну роботу результат як індивідуальних, так і колективних зусиль на всіх рівнях у масштабі всієї організації Альянсу. Твердо закріплені та постійно допрацьовуються політичні рамки та керівні вказівки щодо заохочення гендерної рівності та різноманітності. Серед найбільш неврегульованих проблем нині залишаються насильство на сексуальному і ген- дерному грунті в умовах конфліктів, відсутність ефективних інституційних механізмів захисту представників гендерних, расових, релігійних меншин, недостатня участь жінок у мирному процесі тощо. Ці та інші питання залишаються сьогодні вкрай актуальними та вимагають проведення ретельних досліджень. Досвід країн-членів НАТО становить інтерес і для Збройних Сил України, особливо з огляду на те, що сьогодні в українській армії мають місце прояви дискримінації та насильства за ознакою статі, упередженого ставлення, агресії та відкритого цькування представників ЛГБТ-спільноти тощо [3; 15].

Аналіз останніх досліджень i публікацій. Аналізуючи стан наукового розроблення 
проблематики, маємо підстави говорити, що більшість праць вітчизняних дослідників були присвячені висвітленню питання впровадження гендерної політики у Збройні сили, головним чином участі жінок у військовій справі $[6 ; 11 ; 12]$. Розглядався історичний досвід вирішення гендерних питань у вітчизняних збройних формуваннях, аналізувалися досягнення і проблеми гендерної політики в арміях провідних країн світу $[1 ; 5$; $7 ; 16 ; 18]$, деякі роботи спиралися на результати соціологічних досліджень [4]. Особливостям формування гендерної ментальності у Збройних Силах України з урахуванням досвіду провідних країн-членів НАТО присвячена праця С. Салкуцан і Л. Кримець [17], однак не були належно висвітлені питання запровадження політики щодо гендерної, релігійної, расової, національної різноманітності, включеності та рівних можливостей у Збройних силах, впровадження заходів щодо протидії гендерному насильству. Саме цим питанням і присвячується пропонована стаття.

Постановка завдання. 3 огляду на недослідженість та актуальність порушеної проблематики основним завданням пропонованої статті вважаємо аналіз досвіду деяких країн-членів НАТО щодо вирішення питань, пов'язаних із інтеграцією гендерної рівності та різноманітності у Збройні сили.

Виклад основного матеріалу дослідження. Сьогодні вже усталеною є думка, що склад Збройних сил країни має відображати усі різноманіття суспільства. Це підвищує репрезентативність армії, iї підтримку з боку суспільства та забезпечує легітимність Збройних сил перед суспільством. Легітимність, у свою чергу, підвищує боєздатність Збройних сил. Крім того, Збройні сили виступають як роботодавець, надають робочі місця, можливість здобути освіту та досвід служби за межами країни, домогтися професійного зростання.

Сьогодні Збройні сили різних країн відкривають для жінок дедалі більше посад, дедалі більшого значення набуває гендерна рівність та усунення перешкод на шляху дієвої участі жінок у військовій справі, проте так було не завжди. Довго участь жінок у військовій діяльності викликала суперечки у суспільстві. Аргументи противників гендерної рівності головним чином стосувалися фізичної та психологічної неспроможності жінок проходити військову службу, проблеми забезпечення згуртованості, боєготовності та підтримки морального духу підрозділу, але подібні аргументи вже неодноразово спростовувалися соціологічними дослідженнями. Зокрема, було з'ясовано, що змішані підрозділи є більш схильними до емпатії (співпереживання), проявляють цікавість до національних, культурних особливостей країн, де проводилася операція, а також віддавали перевагу несиловим формам взаємодії 3 місцевим населенням [12].

Сьогодні надзвичайно актуальним для багатьох держав Альянсу постає питання щодо служби у Збройних силах представників ЛГБТспільноти. Гомосексуали та лесбійки завжди служили у Збройних силах, навіть незважаючи на те, що вони були змушені приховувати свою сексуальну орієнтацію і часто ставали жертвами дискримінаційних заходів і дій. Під впливом більш широкої громадської тенденції багато провідних держав світу проводять політику, спрямовану на припинення дискримінації та створення рівних можливостей всередині Збройних сил. Збройні сили щонайменше 50 держав мають чітку політику, яка підтверджує, що лесбійки, геї та бісексуали можуть служити. Крім того, 18 країн (включаючи 11 країн-членів НАТО) дозволяють служити у своїх Збройних силах трансгендерним людям, a саме: Австралія, Австрія, Бельгія, Болівія, Канада, Чехія, Данія, Естонія, Фінляндія, Франція, Німеччина, Ізраїль, Нідерланди, Нова Зеландія, Норвегія, Іспанія, Швеція та Велика Британія. Тим не менше, залишаються Збройні сили, де всі посади закриті для ЛГБТ-осіб. У деяких країнах вони часом ставали об'єктом вкрай втручальних розслідувань щодо власного приватного життя, $\mathrm{i}$ на них здійснювався тиск із вимогою зізнатися під загрозою оприлюднення результатів цих розслідувань і притягнення до кримінальної відповідальності [10, с. 10].

Для реалізації бачення сучасних, різноманітних Збройних сил, здатних залучати й утримувати талановиті кадри, у країнах-членах Альянсу визнають необхідність нових ініціатив і підвищення рівня культурної трансформації в усіх сферах. Пріоритетними напрямами визначені подолання бар'єрів для вербування, утримання та просування по службі жінок та інших груп, які традиційно недостатньо представлені у Збройних силах, і протистояння гендерним домаганням, дискримінації та зловживанням. Наголошується на тому, що для сприяння різноманітності у Збройних силах необхідно:

- забезпечити включення як жінок, так і чоловіків до всіх підрозділів, котрі матимуть прямий контакт із цивільним населенням і відповідатимуть більш конкретним оперативним потребам 
(«комплектуванню»), що вимагають наявності жіночого особового складу. Наприклад, у контактних групах, на контрольно-пропускних пунктах та у пошукових операціях, у наданні послуг перекладачів, під час операцій із затримання, надання невідкладної медичної допомоги й у взаємодії 3 місцевими організаціями;

- переконатися, що на спеціалізованих гендерних посадах (гендерні консультанти, гендерні координатори тощо) можуть працювати кваліфіковані спеціалісти - як жінки, так і чоловіки;

- проводити політику нульової толерантності до сексуальних домагань i насильства між військовослужбовцями;

- контролювати використання дисциплінарних заходів за порушення правил політики нульової толерантності, щоб гарантувати їх належне та пропорційне застосування тощо.

Деякі дослідження ефективності малих груп виявили, що наявність різноманітності (зокрема расового та гендерного різноманіття) пов'язана із кращим вирішенням творчих проблем, інноваціями й удосконаленням прийняття рішень [22, с. 4].

Сполучені Штати Америки. У сучасних Збройних силах США, за останніми даними, служать понад 200 тис. жінок, що приблизно становить $15 \%$ від загальної чисельності військовослужбовців, однак так було не завжди. Наприклад, у спеціальному законі 1993 р. жінкам було заборонено служити на борту військових кораблів, а починаючи 31994 р. Сполучені Штати проводили загальну політику обмеження служби жінок у Збройних силах. У правилах ведення сухопутних боїв (DGCDAR) існувала пряма заборона залучення жінок до служби у підрозділах нижче бригадного рівня (ведення безпосередніх бойових дій) і вводилися додаткові чотири дискреційні обмеження [18, с. 216]. Жінкам могли обмежувати посади, на яких виконання обов'язків було пов'язано 3 конфіденційною інформацію, безпосереднім перебуванням у наземних бойових підрозділах, проведенням розвідувальних операцій на великі відстані та діяльністю спеціальних місій оперативних сил, виконанням фізично складних завдань.

Протягом 2013-2015 рр. у Збройних силах США було проведено понад 30 досліджень та оглядів, у яких розглядалися інституційні, культурні, фізичні фактори, пов'язані з гендерною інтеграцією; порівнювалися показники чоловічих і гендерно інтегрованих підрозділів у різних бойових завданнях; визначався вплив гендерної інтеграції у невеликих підрозділах на ефективність місії, втому, навантаження, згуртованість і готовність. Крім того, були проведені консультації 3 партнерами та союзниками, включаючи Австралію, Канаду та Ізраїль. Як результат, було оголошено про відкриття для жінок приблизно 213600 закритих посад, котрі охоплювали близько 52 закритих військових спеціальностей [23]. У 2017 р. відбувся перший випуск жінок школи морської піхоти США [25].

Серед американських жінок-військовослужбовців 40\% представниць расових і національних меншин (серед чоловіків - менше 25\%). Станом на 2009 р. афроамериканки становили понад 15\% жінок-офіцерів на дійсній службі та близько $33 \%$ жінок-сержантів і солдатів [4, с. 232]. У жовтні 2011 р. вперше в історії Збройних сил США афроамериканка Марсіа Андерсон після 30 років служби в армії отримала звання генерал-майора. Вона вважає, що можливості для всіх рівні, i будьхто, хто хоче стати керівником, отримує хорошу підтримку [24].

У 2008 р. американка Ен Данвуді стала першою в історії США жінкою, котра отримала звання генерала. Станом на 2020 р. це звання отримали ще п'ять жінок. Лорі Робінсон - генерал Повітряних сил США (2014), стала першою в історії Збройних сил США жінкою-генералом, яка очолювала міжвидове Об'єднане командування. Під час північнокорейської кризи 2017 р. вона очолювала Північне командуванням США та Командування повітряно-космічної оборони Північної Америки. Лорі Робінсон зазначила: «Сьогоднішні Збройні сили набагато більш гендерно інтегровані, ніж будь-коли раніше. Жінки більше не виключаються з бойових завдань будьяких видів» [8].

У березні 2021 р. Президент США Джо Байден оголосив про висунення двох жінок-генералів на посади командувачів бойових командувань. Генерал Жаклін Ван Овост мала очолити Транспортне командування Збройних сил США, а генерал-лейтенант Лора Ричардсон - Південне командування Збройних сил США. Байден назвав Ван Овост i Лору Річардсон «двома видатними та висококваліфікованими жінками-воїнами й патріотками». Він підкреслив, що вони обидві зробили військову кар'єру, «показавши незрівнянну майстерність, доброчесність і обов'язок перед країною, а інші жінки у Збройних силах США мають брати їхні досягнення за приклад» [2].

За останні кілька десятиліть у США відбулися швидкі зміни у деяких законах і політиці щодо різноманітності, включеності та рівних 
можливостей, зокрема щодо жінок, котрі служать за бойовими спеціальностями, та включення ЛГБТ-осіб до особового складу Збройних сил. Деякі із цих змін залишаються суперечливими та мають постійні юридичні виклики. Для прикладу, 30 листопада 2010 р. Міністерство оборони США оприлюднило ключові висновки робочої групи щодо скасування обмежень для проходження служби геями та лесбійками. Тоді понад дві третини військовослужбовців, які взяли участь в опитуванні, не заперечували проти служби відкритих геїв і лесбійок. Більш високий рівень невдоволення показали військовослужбовці, що служили у підрозділах спецпризначення, та представники капеланського корпусу (згідно з опитуванням Міністерства оборони, проведеним серед військовослужбовців 2015 р., приблизно 3,9\% чоловіків і 16,1\% жінок ідентифікували себе як геїв, лесбійок чи бісексуалів) [22, с. 39]. У 2015 р. Міністерством оборони США було підтверджено право всіх військовослужбовців служити, просуватися по службі й оцінюватися на підставі лише індивідуальних достоїнств, придатності, здібностей і результатів роботи у середовищі, вільному від незаконної дискримінації за ознакою раси, кольору шкіри, національного походження, релігії, статі (включаючи гендерну ідентичність) або сексуальної орієнтації.

Оборонним відомством США розроблено значний перелік інструкцій для керівників усіх рівнів, у тому числі із протидії гендерному насильству. Для прикладу наведемо перелік завдань командира армії США, що стосуються запобігання гендерному насильству. 3 метою профілактики виникнення випадків гендерного насильства командир повинен: створити командну атмосферу недопущення гендерного насильства, що грунтується на взаємній повазі та довірі, визнавати та приймати різноманіття та цінувати внески всіх членів команди; наголошувати на тому, що сексуальні посягання порушують основні цінності професіонала Збройних сил та остаточно знищують злагодженість підрозділу та довіру, яка є надзвичайно важливою для успіху виконуваної місії; нагадувати (для Міністерства оборони та військовослужбовців), що сексуальне домагання має правові наслідки для тих, хто вчиняє такі злочини; відстежувати настрої та загальну атмосферу в підрозділі, вживати належних заходів у разі виявлення негативних тенденцій. У разі виникнення випадків насильства командиру пропонуються конкретні рекомендації щодо його подальших дій, викладені у спеціальному методичному посібнику
Commanders Checklist for Unrestricted Reports of Sexual Assault [21].

Німеччина. Різноманітність у Бундесвері - це не лише імплементація принципу рівності, закріпленого в Основному законі та Законі «Про рівні можливості для жінок і чоловіків, які проходять військову службу у Бундесвері», але також підписання 2012 р. Федеральним міністерством оборони «Хартії різноманітності». Різноманітність у Бундесвері означає привабливість військової служби для широких верств населення.

3 метою реалізації положень Закону «Про рівні можливості для жінок і чоловіків, які проходять військову службу у Бундесвері» із 2005 р. у Збройних силах Німеччини з'являються офіцери, які відповідають за забезпечення гендерної рівності. Вони беруть участь у кадрових, організаційних і соціальних заходах, що стосуються суміщення сімейного життя зі службою, захисту від сексуальних домагань на робочому місці, гарантування рівних можливостей для жінок і чоловіків на службі. Йдеться про запобігання й усунення гендерної дискримінації.

Офіцери із забезпечення гендерної рівності є важливими контактними особами для жінок-військовослужбовців і персоналу з числа ЛГБТ-осіб, котрі зазнають утиску та дискримінації з боку керівництва, стають об'єктом знущань. Член Парламентського комітету 3 питань у сфері Збройних сил порекомендував розширити функції цих офіцерів, аби вони були присутні на атестаціях, брали участь у застосуванні дисциплінарних заходів і претензійних провадженнях, супроводжували жінок-військовослужбовців, на їх прохання, під час допитів у разі виникнення інцидентів, пов'язаних із розслідуванням випадків сексуального домагання [9].

Як визнала міністр оборони Німеччини Аннегрет Крамп-Карренбауер, донедавна військовослужбовці-гомосексуалісти систематично піддавалися у Бундесвері дискримінації. Їм було важко просуватися по службі, домагатися успішних кадрових рішень. У вересні 2019 р. А. КрампКарренбауер наказала своєму відомству підготувати законопроект, зокрема про реабілітацію тих військовослужбовців, які постраждали та були засуджені у військах через свої нетрадиційні дії. Крім того, Центр військової історії та соціальних наук Бундесверу дістав замовлення на дослідження про показники гомосексуалізму у війську за період від 1955 до 2000 рр. [14]. Після оприлюднення результатів дослідження, котре документує «систематичну дискримінацію» в Бундесвері, 
А. Крамп-Карренбауер офіційно перепросила за десятиліття дискримінації. Крім того, урядом Німеччини був схвалений закон, що передбачає грошові компенсації геям-військовослужбовцям, які зазнали дискримінації в армії до 2000 р. Закон скасовує винесені вироки військових судів із виплатою символічної суми у 3000 євро як компенсації за кожен із них. Тi, хто був звільнений зі служби чи переведений, також матимуть право на компенсацію. Закон також стосуватиметься людей, котрі зазнали дискримінації у комуністичній Національній народній армії Східної Німеччини, яка припинила своє існування 1990 р. Міністр оборони висловила сподівання, що закон «закриє цей темний розділ в історії Збройних сил». «Ми не можемо виправити те, що постраждали ці люди, але ми хочемо показати приклад там, де це можливо», - зазначила А. Крамп-Карренбауер. За оцінкою Міністерства оборони, заявки мали подати близько 1000 осіб. Водночас правозахисники заявили, що фінансові збитки тодішніх військових від Збройних сил Німеччини «набагато перевищують запропоновану суму», бо постраждалі більше не отримували підвищення по службі, їх звільняли або позбавляли пенсії [13].

Протягом останніх років забезпечення особовим складом було однією 3 головних проблем Міністерства оборони Німеччини. Зменшення кількості бажаючих служити в армії було пов'язано, зокрема, з демографічними змінами, що відбувалися у країні. Збройні сили протидіяли цьому різними програмами, які мали за мету зробити військову службу більш привабливою. Із 2016 до травня 2020 pp. Збройні сили Німеччини збільшилися приблизно на 9 тис. осіб, їх чисельність становила 185 тис. військовослужбовців. Планові показники з чисельністю засвідчили, що вперше за останні роки не було потреби у реєструванні кадрового некомплекту. Серед військовослужбовців - 22800 жінок, що становить $12,3 \%$ від загальної чисельності. На цивільних посадах Бундесверу жінки становлять до $20 \%$.
Бундесвер є другим найпопулярнішим роботодавцем для молоді після поліції, а як роботодавець для фахівців він вперше потрапив у топ-20 [19].

Сьогодні Бундесвером визначені чіткі цілі: стале усунення системних недоліків щодо служби жінок; підвищення рівня усвідомлення керівним складом рівних можливостей і пов'язаних із ними змін; культура лідерства; підвищення лояльності персоналу щодо використання потенціалу різноманітності; посилений професійний розвиток жінок на керівних посадах; покращення можливості участі у кар'єрі для працівників, які мають сімейні обов'язки; реальна оцінка впровадження заходів і результатів щодо рівних можливостей у рекламі персоналу для подальшого залучення таланту [26].

Висновки. Підводячи підсумки, зазначимо, що згідно 3 директивою НАТО 2017: 040-001 [20] поняття «гендер» не спрямовує ексклюзивний фокус уваги виключно на жінок. Гендерна інтеграція є основою формування гендерної ментальності та визначається як стратегія, що використовується для досягнення гендерної рівності у Збройних силах через активізацію залучення як жінок, так і чоловіків до виконання завдань за призначенням на всіх рівнях для врахування інтересів і досвіду обох статей. Важливим аспектом у забезпеченні рівних можливостей для військовослужбовців обох статей залишається контроль за процесами набору та просування по службі військовослужбовців різних статей, а також здійснення активного моніторингу заходів, спрямованих на утримання персоналу та забезпечення необхідного балансу між службою й особистим життям військовослужбовців [17, с. 108]. Перспективними напрямами подальших наукових студій можуть стати дослідження гендерної, національної та релігійної різноманітності у Збройних силах країн-членів НАТО, а також вивчення інституційних, культурних, фізичних факторів, пов'язаних із гендерною інтеграцією в армії.

\section{Список літератури:}

1. Актуальні проблеми гендерної політики у Збройних Силах України : навчально-методичний посібник / В.П. Кротиков, В.Л. Топальський, В.М. Малюга та ін. ; за заг. ред. Б.П. Андресюка. Київ, 2011. 112 с.

2. Байден висунув двох жінок-генералів на посади бойових командувачів ЗС CШA. URL: https://www.ukrinform.ua/rubric-world/3204416-bajden-visunuv-dvoh-zinokgeneraliv-na-posadi-bojovihkomanduvaciv-zs-ssa.html (дата звернення: 1.6.2021).

3. Беца О. Багато військовослужбовців мовчать про свою орієнтацію: як живуть в Україні ЛГБТвійськові. URL: https://bezbroni.net/stories/bagato-viiskovosluzhbovciv-movchat-pro-svoyu-orijentaciyuyak-zhivut-v-ukraini-lgbt-viiskovi?fbclid=IwAR1y5CHq5OP_0BQ5eRQg0WZun4eEyA1qCb6fFHn7_ cZi9tvokKms6wqYaEg (дата звернення 23.11.2021). 
4. Богайчук В.Ж., Єфімова В.В. Досвід Збройних сил США з проблем гендерної рівності. Вісник Наиіональної академії оборони. 2010. № 3 (16). С. 230-237.

5. Гендерна політика у Збройних Силах України: проблеми теорії та практики : монографія / В.П. Кротиков, В.Л. Топальський, В.М. Малюга та ін. ; за заг. ред. О.М. Олійника. Київ, 2012. 334 с.

6. Грицай I.O. Проблема гендерного балансу в національних збройних силах: теоретико-прикладний аспект. Науковий вісник публічного та приватного права. Теорія та історія держави і права. Вип. 5. 2016. С. 3-8.

7. Дрозд О. Гендерна рівність у сфері безпеки й оборони: міжнародний досвід. Адміністративне право i проиес. 2020. № 10. С. 105-110.

8. Женщины - важное звено Вооруженных сил CША. URL: https://share.america.gov/ru/женщиныважное-звено-вооруженных-си/ (дата звернення 10.5.2021).

9. Інституційна культура. Як сприяти розвитку інклюзивної культури та протистояти застосуванню патріархальних норм у секторі безпеки та оборони / підготовлено Еммікі Рус (Emmicki Roos), OOH-Жінки, $2019.8 \mathrm{c}$

10. Каллум Уотсон. Гендерні питання в секторі оборони. Збірник інформаційно-методичних матеріалів «Гендерні питання в секторі безпеки». Женева, 2020. 67 c. URL: https://www.osce.org/files/f/documents/ $\mathrm{a} / \mathrm{b} / 468957 . p d f$ (дата звернення 10.5.2021).

11. Клименко Н.Г. Роль і місце жінки-військовослужбовця в Україні. Економіка та держава. № 5. 2014. C. $116-119$.

12. Марценюк Т. Жінки у збройних силах світу та України: на шляху до інтеграції. 2016. URL: https://povaha.org.ua/zhinky-u-zbrojnyh-sylah-svitu-ta-ukrajiny-na-shlyahu-do-intehratsiji/ (дата звернення 23.11.2021).

13. Німеччина виплатить компенсації геям за дискримінацію в армії URL: https://suspilne.media/83046nimeccina-viplatit-po-3-tisaci-evro-diskriminovanim-v-armii-geam-vijskovim/ (дата звернення 1.6.2021).

14. Реабілітація військовослужбовців-гомосексуалістів. Як функціонує Бундесвер URL: https://bintel.org.ua/analytics/voenni-voprosy/yak-funkcionuye-bundesver/\#: :text=ociб.,Бундесверу\%20 жінки\%20становлять\%20до\%2020\%20\%25 (дата звернення 1.6.2021).

15. Савчук I. Кольори української армії: геї та лесбійки на передовій. URL: https://uain.press/articles/ geyi-ta-lesbijky-na-peredovij-960692 (дата звернення: 23.11.2021).

16. Салкуцан С.М., Кримець Л.В. Гендерна політика НАТО: історичний аспект і досвід інтеграції. Наука і оборона. 2019. № 3. С. 21-24.

17. Салкуцан С., Кримець Л. Особливості формування гендерної ментальності в Збройних Силах України з урахуванням досвіду провідних країн-членів НАТО. Вісник Національного університету оборони України. 2019. № 2 (52). С. 102-111.

18. Філяніна Л.А. Армія vs жінки: питання гендерної рівності в деяких сучасних Збройних силах світу. Науковий вісник Дніпропетровського державного університету внутрішніх справ. Спец. випуск № 3. 2018. C. 215-219.

19. Чисельність Бундесверу знову збільшується. Як функціонує Бундесвер. URL: https://bintel.org.ua/ analytics/voenni-voprosy/yak-funkcionuye-bundesver/\#: :text=ociб.,Бундесверу\%20жінки\%20становлять\%20до\% $2020 \% 20 \% 25$ (дата звернення 10.5.2021).

20. Bi-Strategic Command Directive (Bi-SCD) 040-001 Integrating UNSCR 1325 and Gender Perspective into the NATO Command Structure, 17th October 2017. URL: https:/www.act.nato.int/images/stories/structure/ genderadvisor/nu0761.pdf (дата звернення 17.5.2021).

21. Commanders Checklist for Unrestricted Reports of Sexual Assault. URL: www.sapr.mil/public/docs/ miscellaneous/toolkit/COMMANDER_CHECKLIST.pdf (дата звернення 1.6.2021).

22. Diversity, Inclusion, and Equal Opportunity in the Armed Services: Background and Issues for Congress. December 23, 2015 - June 5, 2019. 60 p. URL: https://sgp.fas.org/crs/natsec/R44321.pdf (дата звернення 15.6.2021).

23. Fact Sheet: Women in Service Review (WISR) Implementation. URL: https://dod.defense.gov/Portals/1/ Documents/pubs/Fact_Sheet_WISR_FINAL.pdf (дата звернення 15.6.2021).

24. Marcia Aderson: first black female two-star general in US Army. URL: http://audiorazgovornik.ru/ about-american-life-in-american-english/871--q-qq-think-youre-an-auditory-or-visual-learner-scientists-say-itsunlikely (дата звернення 10.5.2021).

25. TIMELINE: A History Of Women In The US Military. URL: https://taskandpurpose.com/timeline-historywomen-us-military/ (дата звернення 11.7.2021).

26. VielfaltinderBundeswehr.URL:https://www.bundeswehr.de/de/ueber-die-bundeswehr/selbstverstaendnisbundeswehr/chancengerechtigkeit-bundeswehr/vielfalt-bundeswehr (дата звернення 10.5.2021). 


\section{Maraeva V.V., Danilievska O.V. INTRODUCING GENDER EQUALITY IN THE ARMED FORCES: THE EXPERIENCE OF NATO MEMBER STATES}

Gender mainstreaming is the basis for the formation of a gender mentality and is defined as a strategy used to achieve gender equality in the Armed Forces by intensifying the involvement of both women and men in the assigned tasks at all levels. NATO members recognize the need for new initiatives and cultural transformation in all areas in order to realize the vision of a modern, diverse Armed Forces capable of attracting and retaining talented personnel. Overcoming barriers to the recruitment, retention and promotion of women and other groups, which are traditionally underrepresented in the Armed Forces, and combating gender harassment, discrimination and abuse are identified as priorities. NATO has a strong policy framework and guidelines for promoting gender equality and diversity. Among the most unresolved issues are sexual and gender-based violence in conflict situations, the lack of effective institutional mechanisms to protect members of gender, racial and religious minorities, insufficient participation of women in the peace process, and so on. These and other issues remain extremely relevant today.

The proposed article uses the examples of the United States and Germany to review the experience of NATO member countries in integrating gender equality and diversity into the Armed Forces. Opponents of gender equality over the physical and psychological inability of women to serve in the military, the problems of cohesion, combat readiness, and morale support have been repeatedly refuted by opinion polls. In recent years, there have been rapid changes in laws and policies on diversity, inclusion and equal opportunities in some countries. In particular, regarding women serving in combat specialties and the inclusion of LGBT people in the Armed Forces. And while some of these changes remain controversial and have ongoing legal challenges, this experience deserves the attention of scholars.

Key words: gender, gender equality, NATO, armies of NATO member states, integration of diversity into the Armed Forces, discrimination on the grounds of sex. 